Southern Illinois University Carbondale

OpenSIUC

Peer-reviewed Articles

Department of Animal Science, Food and Nutrition

9-2015

\title{
The Effects of Cinnamaldehyde, Monensin and Quebracho Condensed Tannin on Rumen Fermentation, Biohydrogenation and Bacteria in Continuous Culture System
}

\author{
A Ishlak \\ M Günal \\ Department of Animal Science, Süleyman Demirel University, 32200 Isparta, Turkey \\ A A AbuGhazaleh
}

Follow this and additional works at: http://opensiuc.lib.siu.edu/asfn_articles

Publisher (Elsevier) Website PDF: http://www.sciencedirect.com/science/article/pii/

S0377840115001844

\section{Recommended Citation}

Ishlak, A, Günal, M and AbuGhazaleh, A A. "The Effects of Cinnamaldehyde, Monensin and Quebracho Condensed Tannin on Rumen Fermentation, Biohydrogenation and Bacteria in Continuous Culture System." Animal Feed Science and Technology 207 (Sep 2015): 31-40. doi:10.1016/j.anifeedsci.2015.05.023.

This Article is brought to you for free and open access by the Department of Animal Science, Food and Nutrition at OpenSIUC. It has been accepted for inclusion in Peer-reviewed Articles by an authorized administrator of OpenSIUC. For more information, please contact opensiuc@lib.siu.edu. 


\title{
The effects of cinnamaldehyde, monensin and quebracho condensed tannin on rumen fermentation, biohydrogenation and bacteria in continuous culture system
}

\author{
A. Ishlak ${ }^{\text {a }}$, M. Günal ${ }^{\text {b }}$, A.A. AbuGhazaleh ${ }^{\text {a,* }}$ \\ a Department of Animal Science, Food and Nutrition, Southern Illinois University Carbondale, IL 62901, United States \\ b Department of Animal Science, Süleyman Demirel University, 32200 Isparta, Turkey
}

\section{A R T I C L E I N F O}

\section{Article history:}

Received 14 December 2014

Received in revised form 22 April 2015

Accepted 30 May 2015

Available online $\mathrm{xxx}$

\section{Keywords:}

Cinnamaldehyde

Condensed tannin

Monensin

Fermentation

Trans fatty acid formation

Continuous culture system

\begin{abstract}
A B S T R A C T
The objective of this experiment was to evaluate the effects of different feed additives (cinnamaldehyde, monensin, and quebracho condensed tannin extract) on fermentation, trans fatty acids (FA) formation and selected strains of rumen bacteria. Four continuous culture systems were used in $4 \times 4$ Latin square designs with 4 periods of 10 days each. Treatment diets were: control diet (44:56 forage to concentrate; CON), control plus cinnamaldehyde (CIN) at $400 \mathrm{mg} / \mathrm{L}$, control plus monensin $(\mathrm{MON})$ at $12 \mathrm{mg} / \mathrm{L}$, and control with quebracho condensed tannin extract (QTAN) at $100 \mathrm{~g} / \mathrm{kg}$ of diet (DM basis). Fermenters were fed treatment diets three times daily at $120 \mathrm{~g} /$ day and overflow (effluent) samples were collected from each fermenter on days 8,9 and 10 of each period to estimate nutrients digestibility and FA composition. On day 10 of each period, three samples were collected from each fermenter at 3 and $6 \mathrm{~h}$ post morning feeding for volatile fatty acids (VFA), ammonia-N and bacterial analyses. Compared with the CON diet, feed additives had no effects $(P>0.05)$ on apparent dry matter (DM), neutral detergent fiber (NDF) and organic matter (OM) digestibility but apparent protein digestibility decreased $(P<0.01)$ with the QTAN and CIN diets. Compared with the CON diet, the concentration of acetate decreased $(P<0.05)$ with the MON and CIN diets. The concentration of propionate increased $(P<0.05)$ with the MON and QTAN diets and was greatest with the MON diet. Ammonia-N concentration decreased $(P<0.01)$ with all feed additives and was least with the QTAN diet. The concentration of C18:0 decreased $(P<0.01)$ with the three feed additives and was least with the MON diet. Concentration of trans C18:1 and vaccenic acid (VA) increased $(P<0.05)$ with the MON and CIN diets and was greatest with the MON diet. Compared with the CON diet, the concentration of $c 9 t 11$ CLA increased $(P<0.05)$ only with the QTAN diet. The DNA abundance of Butyrivibrio proteoclasticum decreased $(P<0.05)$ with the MON and CIN diets while the DNA abundance for Butyrivibrio VA increased $(P<0.05)$ with all feed additives compared with the CON diet. Feed additives had no effects $(P>0.05)$ on the DNA abundance of Anaerovibrio lipolytica and Butyrivibrio SA. In conclusion, results demonstrate that the feed additives used in this study affected the fermentation and biohydrogenation process.
\end{abstract}

\footnotetext{
Abbreviations: ADF, acid detergent fiber; $\mathrm{BH}$, biohydrogenation; CIN, cinnamaldehyde; CLA, conjugated linoleic acids; CON, control; CP, crude protein; DM, dry matter; EO, essential oils; FA, fatty acids; MON, monensin; NDF, neutral detergent fiber; OM, organic matter; QTAN, quebracho condensed tannin; VA, vaccenic acid; VFA, volatile fatty acids.

* Corresponding author at: Department of Animal Science, Food and Nutrition, Southern Illinois University Carbondale, Agriculture Bldg, Room 119, Carbondale, IL 62901-4417, United States. Tel.: +1 618453 1767; fax: +1 6184535231.

E-mail address: aabugha@siu.edu (A.A. AbuGhazaleh).
} 
Addition of feed additives reduced the formation of C18:0 but only MON and CIN increased VA formation. MON and CIN effects on VA formation may in part be explained by their effects on B. proteoclasticum.

(c) 2015 Elsevier B.V. All rights reserved.

\section{Introduction}

In recent years, a considerable amount of research work has focused on the fatty acid (FA) composition of ruminant products for the effects of their consumption on human health. Especially, FA such as conjugated linoleic acids (CLA) are active in the prevention of cancer, obesity and atherosclerosis in humans (Crumb, 2011). The most common CLA isomer is the c9t11 CLA, which is formed in the rumen during biohydrogenation (BH) of dietary C18:2n6 or in body tissue by $\Delta^{9}$-desaturase from VA, another intermediate in ruminal BH of C18 unsaturated FA (Griinari et al., 2000).

Different dietary strategies have been used to decrease the rate of ruminal $\mathrm{BH}$ such as feeding plant and marine oils (AbuGhazaleh and Jacobson, 2007; Gudla et al., 2012), or algae (AbuGhazaleh et al., 2009) and increasing forage to concentrate ratio (AbuGhazaleh and Jacobson, 2007). Several feed additives have been also proposed to increase the content of CLA in milk fat. Ionophores such as monensin are known to reduce methane production by inhibiting the growth of gram-positive bacteria that produce hydrogen and that may interfere with the process of ruminal BH. Ionophores have been shown to decrease the rate of ruminal BH of unsaturated FA in vitro (Fellner et al., 1997) and increase the content of CLA in milk fat (AlZahal et al., 2008). However, the use of ionophores as a feed antibiotic in livestock has been banned in certain counties (e.g. EU) and criticized by others because of the possible presence of residues in food and the emergence of resistant strains of bacteria. Therefore, plant secondary metabolites such as essential oils (EO), saponins and tannins have been suggested as a potential means to manipulate bacterial populations involved in ruminal BH to modify the FA composition of ruminantderived food products such as milk and meat. Although several studies have examined plant secondary metabolites effects on rumen fermentation and the greenhouse gases production (Makkar et al., 1995; Sliwinski et al., 2002; Cardozo et al., 2004; Busquet et al., 2006; Chaves et al., 2008; Hassanat and Benchaar, 2012), only few studies evaluated the effects of these compounds on BH. Additionally, little information is currently available about the effects of these plant metabolites on rumen microbial ecology, particularly, bacterial species believed to be involved in the BH process. Therefore, the main objective of this study was to evaluate the effects of two secondary metabolites such as QTAN from quebracho trees (Schinopsis balansae) and cinnamaldehyde and monensin on rumen trans FA formation and selected strains of rumen bacteria using continuous culture systems.

\section{Materials and methods}

\subsection{Experimental design}

Four $1700 \pm 12 \mathrm{~mL}$ continuous culture fermenters (Stern and Hoover, 1990) were used in $4 \times 4$ Latin square designs with 4 periods of 10 days each. The first 7 days were used for adaptation and last 3 days for samples collection. Treatment diets were fed at $120 \mathrm{~g} /$ day (DM basis) in three equal portions during the day at 0800,1500 and $2200 \mathrm{~h}$. The diets were: (1) 44:56 forage to concentrate (CON), (2) CON plus cinnamaldehyde at $400 \mathrm{mg} / \mathrm{L}$ (1200 mg/day) (CIN), (3) CON plus monensin at $12 \mathrm{mg} / \mathrm{L}$ (36 mg/day) (MON), and (4) CON with quebracho condensed tannin at $100 \mathrm{~g} / \mathrm{kg}$ of diet DM (QTAN; Tables 1 and 2). The forage consisted of grass hay while the concentrate mix contained corn, soybean meal, soy hulls, corn oil and minerals. Quebracho condensed tannin (purity of 0.70; Tannin Corporation, Peabody, MA, USA) was added to the diet by partially replacing some of the hay, corn and soy hulls. Cinnamaldehyde $\left(\mathrm{C}_{9} \mathrm{H}_{8} \mathrm{O}\right.$, purity of 0.98 , Sigma-Aldrich, St. Louis, MO, USA); and monensin (Acros Organics Company, NJ, USA) were dissolved in ethanol and added directly into each fermenter with each feeding.

\subsection{Continuous culture}

Ruminal fluid was collected from a fistulated lactating Holstein cow fed (55:45 forage to concentrate diet; DM basis). At $2-4 \mathrm{~h}$ after the morning feeding, ruminal contents were collected into a plastic bag under anaerobic conditions. The rumen contents brought to the laboratory; were strained through 2 layers of cheesecloth, and used within 15 min. Approximately $1300 \mathrm{~mL}$ of the ruminal fluid were added to each of the four fermenters, containing $400 \mathrm{~mL}$ of prewarmed buffer. Cultures were stirred continuously at $120 \mathrm{rpm}$ via a magnetic impeller stirrer unit and fermenter $\mathrm{pH}$ was maintained above 6.2 by adjusting buffer $\mathrm{pH}$ level with $1 \mathrm{~N} \mathrm{NaOH}$ or $1 \mathrm{~N} \mathrm{HCl}$. Fermenters $\mathrm{pH}$ was measured daily before feeding using a portable $\mathrm{pH}$ meter at 0800, 1500 and 2400 . Buffer was delivered continuously at a flow rate of $1.16 \mathrm{~mL} / \mathrm{min}\left(0.10 \mathrm{~h}^{-1}\right.$ liquid dilution rate), using a precision pump. Anaerobic conditions in fermenters were maintained by purged with $\mathrm{N}_{2}$ gas $(80 \mathrm{~mL} / \mathrm{min})$ and fermenter temperature was maintained at $39^{\circ} \mathrm{C}$. Flow rate of each fermenter was recorded every day at 08:00. 
Table 1

Ingredient and chemical composition of treatment diets.

\begin{tabular}{lcc}
\hline & Treatment & \\
\cline { 2 - 3 } & CON & QTAN \\
\hline Ingredient $(\mathrm{g} /$ 100 $\mathrm{g} D \mathrm{M})$ & & \\
Grass hay & 44.0 & 39.0 \\
Soybean meal & 16.0 & 16.0 \\
Ground corn & 28.0 & 24.0 \\
Soy hulls & 9.0 & 8.0 \\
Quebracho condensed tannin & - & 10.0 \\
Corn oil & 2.0 & 2.0 \\
Minerals and vitamins & 1.0 & 1.0 \\
Chemical composition, $g /$ 100 g DM & & \\
DM & 92.0 & 92.7 \\
CP & 12.1 & 13.1 \\
ADF & 24.4 & 22.2 \\
NDF & 40.9 & 39.8 \\
Ash & 5.3 & 5.9 \\
Condensed tannin & - & 7.0 \\
\hline
\end{tabular}

$\mathrm{CON}=$ control, $\mathrm{QTAN}=$ quebracho condensed tannin.

Table 2

Fatty acids composition of treatment diets ( $\mathrm{mg} / \mathrm{g}$ of DM).

\begin{tabular}{lcc}
\hline \multirow{2}{*}{ Fatty acid } & Treatment & \\
\cline { 2 - 3 } & CON & QTAN \\
\hline C14:0 & 0.10 & 0.10 \\
C16:0 & 7.92 & 7.92 \\
C18:0 & 2.33 & 2.33 \\
C18: 1 n 9 & 12.7 & 12.7 \\
C18:2n6 & 30.4 & 30.4 \\
C18:3n3 & 2.95 & 2.95 \\
Total fatty acids & 65.3 & 63.9 \\
\hline
\end{tabular}

CON = control, QTAN = quebracho condensed tannin.

\subsection{Sample collection and analysis}

Starting on days 8, 9 and 10 of each period, the overflow (effluent) were collected into 2 L plastic flasks approximately 3/4th immersed into ice as outlined by AbuGhazaleh and Buckles (2007). Collected effluents were homogenized by stirring and $0.25(\mathrm{v} / \mathrm{v})$ subsamples were pooled into one sample and stored at $-20^{\circ} \mathrm{C}$. Effluent samples were freeze dried and then analyzed for FA and nutrients content (DM, OM, CP, and NDF) to estimate digestibility. Effluent samples were thawed in a $50{ }^{\circ} \mathrm{C}$ water bath and then centrifuged (Beckman J2-21, GMI, Inc. Ramsey, MN, USA) in 250 mL plastic bottles at 500 rpm for $5 \mathrm{~min}$. The supernatant was discarded, and to the sediment, more samples were added and centrifuged again. Finally the remaining sediments were freeze dried for at least $48 \mathrm{~h}$, ground through $1 \mathrm{~mm}$ screen Wiley mill. Dry matter was determined by drying at $105^{\circ} \mathrm{C}$ for $48 \mathrm{~h}$ (AOAC, 1990; Method 930.15). Samples were analyzed for CP (Method 976.05), ether extract (Method 920.39), and ash (Method 942.05) according to AOAC (2000) methods. The neutral detergent fiber (aNDFom) was determined using the Van Soest et al. (1991) procedure. The heat stable amylase and sodium sulphite were used to determine NDF. The acid detergent fiber (ADF) content was determined according to AOAC (1990; Method 973.18). Apparent digestibility was calculated as the difference between the contents in the initial samples and the residues remaining after incubation in the effluent (Khiaosa-Ard et al., 2009).

Treatment diets and effluent samples were methylated using the sodium methoxide $\left(\mathrm{NaOCH}_{3}\right)$ and $\mathrm{HCl}$ two-step procedures as outlined by Kramer et al. (1997) and analyzed in duplicate for FA as described by Gas Liquid Chromatography (GLC) as described by AbuGhazaleh and Jacobson (2007). Apparent biohydrogenation was calculated from C18:1n9, C18:2n6 and C18:3n3 proportions in dietary and effluent C18 FA, assuming that the total C18 FA input equals the total C18 FA output (Lourenço et al., 2008).

Two samples were collected from each fermenter on day 10 of each period at 3 and $6 \mathrm{~h}$ post morning feeding and then composited into one sample per fermenter for volatile fatty acids (VFA), ammonia-N and bacterial analyses. Samples for VFA analyses were mixed with $1 \mathrm{~mL}$ of freshly prepared $25 \%$ meta-phosphoric acid, centrifuged (IEC Centra GP8R, Needham Heights, MA) at $20,000 \times \mathrm{g}$ at $4^{\circ} \mathrm{C}$ for $20 \mathrm{~min}$ and supernatant fluid were collected and stored at $-20^{\circ} \mathrm{C}$ until further analysis. Volatile fatty acids were analyzed on gas chromatograph as described by Jenkins (1987), using 2-ethylbutyric acid as an internal standard. For ammonia-N analysis, collected samples were centrifuged at 20,000 $\times g$ (IEC Centra GP8R, Needham Heights, MA) at $4{ }^{\circ} \mathrm{C}$ for $10 \mathrm{~min}$. The supernatant were acidified with $0.5 \mathrm{~mL} 0.1 \mathrm{~N} \mathrm{HCl}$ then analyzed for ammonia-N by Teco 
Table 3

PCR primers and starting DNA concentration for detection of selected ruminal bacteria.

\begin{tabular}{|c|c|c|c|c|}
\hline Target bacterium & Primer sequences $\left(5^{\prime}-3^{\prime}\right)$ & Starting DNA concentration (ng)/25 $\mu \mathrm{L}$ & Annealing temp $\left({ }^{\circ} \mathrm{C}\right)$ & Product size (bp) \\
\hline A. lipolytica & $\begin{array}{l}\text { F GGGTGTTAGAAATGGATTCC } \\
\text { R CTCTCCTGCACTCAAGAATT }\end{array}$ & 80.5 & 57 & 597 \\
\hline B. proteoclasticus & $\begin{array}{l}\text { F CCTAGTGTAGCGGTGAAATG } \\
\text { R TTAGCGACGGCACTGAATGCCTAT }\end{array}$ & 14 & 62 & 188 \\
\hline Butyrivibrio SA & $\begin{array}{l}\text { F TCCGGTGGTATGAGATGGGC } \\
\text { R GTCGCTGCATCAGAGTTTCCT }\end{array}$ & 18 & 60 & 126 \\
\hline Butyrivibrio VA & $\begin{array}{l}\text { F GCCTCAGCGTCAGTAATCG } \\
\text { R GGAGCGTAGGCGTTTTAC }\end{array}$ & 18 & 60 & 124 \\
\hline
\end{tabular}

Diagnostics kit (Anaheim, USA) using a spectrophotometer. Bacterial samples collected from fermenters were frozen immediately in liquid nitrogen and stored at $-80^{\circ} \mathrm{C}$ until bacterial analysis. Microbial samples were thawed at room temperature and centrifuged at $500 \mathrm{rpm}$ for $15 \mathrm{~min}$, to separate solid and liquid associated bacteria, and the supernatant was transferred to new tubes. The DNA from the supernatants was then extracted using Microbial DNA Isolation kit (MO BIO Laboratories, Inc., USA). Concentration of DNA was measured by BioPhotometer (Eppendorf Scientific, Inc., USA) at A260 = 50 ng dsDNA/ $\mu \mathrm{L}$ using disposable Eppendorf UVette cuvets.

Purified cultures of Anaerovibrio lipolytica (DSMZ No. 3074), Butyribirio VA (DSMZ 10316) and Butyrivibrio SA (DSMZ 10302) were obtained from DSMZ (German resource center for biological material, Germany). Butyrivibrio proteoclasticus (ATCC 51982) was obtained from ATCC (The Global Bioresource center, USA). The purified bacteria were used to generate standard curves in our relative quantitation analyses. Polymerase Chain Reaction (PCR) primers used in the present study are shown in Table 3. The PCR conditions A. lipolytica was described by Potu et al. (2011). The primer pairs for bacteria (A. lipolytica, B. proteoclasticus, Butyrivibrio SA and Butyrivibrio VA) were based on the description of Gudla et al. (2012) and Potu et al. (2011). The specificity of primers was confirmed using the BLAST program in the GeneBank Database. Primer pair for Butyrivibrio proteoclasticum was found online (using IDT, Integrated DNA Technologies). These primers were also tested for the requirements imposed by real-time quantitative PCR. Pure cultures of the previously described bacteria were grown in our laboratory under anaerobic conditions in Hungate tubes as specified by ATCC and DSMZ. The four bacteria were used to generate standard curves for the relative quantitation analyses as described by Potu et al. (2011). Tubes were incubated for 3-5 days at $37^{\circ} \mathrm{C}$ to allow bacterial growth. Cultures were transferred to fresh medium from incubated tubes for 2 or 3 times to avoid dead cells. Approximately $1 \mathrm{~mL}$ of the culture was used to extract DNA as described before.

Individual species-specific real time quantitative PCR (qPCR) were performed using Bio-Rad iCycler MyiQ single color real-time PCR detection system (Bio-Rad laboratories, Inc, Hercules, CA, USA), using fluorescence detection of SYBR green mix (Bio-Rad laboratories, Inc., Hercules, CA, USA) as described by Potu et al. (2011). In one word, $12.5 \mu \mathrm{L}$ SBYR Green mix, $2 \mu \mathrm{L}$ of each primer, $20 \mathrm{ng}$ of sample DNA template and RNAase free water were added to make a total volume of $25 \mu \mathrm{L}$. For initial denaturation, amplification involved one cycle at $95^{\circ} \mathrm{C}$ for $10 \mathrm{~min}$ and then 40 cycles of $95^{\circ} \mathrm{C}$ for $30 \mathrm{~s}$ followed by annealing at the temperatures for $30 \mathrm{~s}$ and then at $72^{\circ} \mathrm{C}$ for $1 \mathrm{~min}$ except for B. proteoclasticum for which amplification involved one cycle at $95^{\circ} \mathrm{C}$ for $3 \mathrm{~min}$ for initial denaturation and then 40 cycles of $95^{\circ} \mathrm{C}$ for $30 \mathrm{~s}$ followed by annealing at $62^{\circ} \mathrm{C}$ for $15 \mathrm{~s}$ and then at $72^{\circ} \mathrm{C}$ for $30 \mathrm{~s}$ (Reilly and Attwood, 1998). Detection of the fluorescent product was set at the last step of each cycle. The melting curve was obtained by slow heating with a $0.1^{\circ} \mathrm{C} / \mathrm{s}$ increment from $65^{\circ} \mathrm{C}$ to $95^{\circ} \mathrm{C}$, with fluorescence collection at $0.1^{\circ} \mathrm{C}$ intervals. Samples were performed in triplicate along with standards of known bacterial DNA concentrations which were prepared in 10 fold dilutions. Samples and known standards $\left(10^{1}-10^{6} \mathrm{ng}\right)$ were assayed on the same plate to allow for the quantification of bacteria present in sample. Standard curves, DNA sample quantification and melting curve analyses were obtained using iQ5 Optical System Software (version 2.1, Bio-Rad Laboratories, Inc., Hercules, CA, USA). Samples were amplified in triplicate along with dilution standards of known bacterial DNA concentrations. Samples and standards were assayed on the same plate to allow for the relative quantification of bacterial DNA present in sample.

\subsection{Statistical analysis}

Data were analyzed as a $4 \times 4$ Latin square design using the PROC MIXED of SAS (SAS Institute, Inc., Cary, NC. Version 9.1, 2003). The statistical model was including: fermenters, diet, and period. Fixed effects were diet and period. Random effect was fermenter. Results were expressed as least square means with standard error of the means. Means were compared using the PDIFF option of SAS. The significance threshold was set at $P<0.05$.

\section{Results}

The effect of treatment diets on nutrients digestibility are presented in Table 4 . Feed additives had no effects $(P>0.05)$ on apparent DM, NDF and OM digestibility compared with the CON diet (Table 4). Compared with the CON diet, apparent protein digestibility decreased $(P<0.01)$ only with the QTAN and CIN diets.

The effect of treatment diets on fermentation is presented in Table 5 . The concentration of acetate decreased $(P<0.05)$ with the MON and CIN diets while the concentration of propionate increased $(P<0.05)$ with the MON and QTAN diets compared 
Table 4

The effect of treatment diets on nutrients digestibility.

\begin{tabular}{|c|c|c|c|c|c|c|}
\hline & \multicolumn{4}{|c|}{ Treatment } & \multirow[t]{2}{*}{ MSE } & \multirow[t]{2}{*}{$P$} \\
\hline & $\mathrm{CON}$ & QTAN & MON & CIN & & \\
\hline \multicolumn{7}{|l|}{ Digestibility, \% } \\
\hline DM & 0.63 & 0.59 & 0.58 & 0.62 & 0.031 & 0.65 \\
\hline True protein & $0.59^{a}$ & $0.39^{\mathrm{b}}$ & $0.57^{a}$ & $0.38^{\mathrm{b}}$ & 0.019 & 0.01 \\
\hline NDF & 0.53 & 0.58 & 0.52 & 0.51 & 0.060 & 0.20 \\
\hline OM & 0.62 & 0.51 & 0.53 & 0.51 & 0.019 & 0.72 \\
\hline
\end{tabular}

a Means within raw with different superscripts differ $(P \leq 0.05)$

b Means within raw with different superscripts differ $(P \leq 0.05)$

$\mathrm{CON}=$ control, $\mathrm{QTAN}=$ quebracho condensed tannin, $\mathrm{MON}=$ monensin, and $\mathrm{CIN}=$ cinnamaldehyde.

Table 5

The effect of treatment diets on volatile fatty acids $(\mathrm{mM})$ and ammonia-N level (mg/dL).

\begin{tabular}{|c|c|c|c|c|c|c|}
\hline & \multicolumn{4}{|c|}{ Treatment } & \multirow[t]{2}{*}{ MSE } & \multirow[t]{2}{*}{$P$} \\
\hline & $\mathrm{CON}$ & QTAN & MON & CIN & & \\
\hline Acetate & $36.9^{\mathrm{a}}$ & $34.9^{\mathrm{a}}$ & $27.8^{b}$ & $29.5^{b}$ & 1.831 & 0.007 \\
\hline Propionate & $22.9^{c}$ & $26.8^{\mathrm{b}}$ & $32.8^{\mathrm{a}}$ & $24.3^{\mathrm{bc}}$ & 1.549 & 0.003 \\
\hline Butyrate & 14.8 & 10.5 & 14.0 & 15.6 & 1.696 & 0.110 \\
\hline Isobutyrate & $1.22^{\mathrm{b}}$ & $1.44^{\mathrm{b}}$ & $1.93^{\mathrm{a}}$ & $1.82^{\mathrm{a}}$ & 0.107 & 0.052 \\
\hline Valerate & 3.75 & 2.72 & 3.78 & 3.24 & 0.409 & 0.147 \\
\hline Isovalerate & 2.17 & 2.4 & 1.88 & 3.00 & 0.331 & 0.108 \\
\hline Acetate: propionate & $1.61^{\mathrm{a}}$ & $1.33^{\mathrm{b}}$ & $0.83^{c}$ & $1.12^{\mathrm{b}}$ & 0.127 & 0.004 \\
\hline Total VFA (mM) & 82.3 & 78.9 & 82.5 & 79.0 & 2.671 & 0.110 \\
\hline $\mathrm{NH}_{3}-\mathrm{N}(\mathrm{mg} / \mathrm{dL})$ & $36.1^{\mathrm{a}}$ & $5.01^{\mathrm{d}}$ & $35.7^{b}$ & $31.1^{c}$ & 0.151 & 0.010 \\
\hline $\mathrm{pH}$ & 6.46 & 6.51 & 6.31 & 6.46 & 0.104 & 0.324 \\
\hline
\end{tabular}

a Means within raw with different superscripts differ $(P \leq 0.05)$.

b Means within raw with different superscripts differ $(P \leq 0.05)$.

c Means within raw with different superscripts differ $(P \leq 0.05)$.

d Means within raw with different superscripts differ $(P \leq 0.05)$.

VFA = volatile fatty acids, $\mathrm{NH}_{3}-\mathrm{N}=$ ammonia $\mathrm{N}, \mathrm{CON}=$ control, $\mathrm{QTAN}=$ quebracho condensed tannin, $\mathrm{MON}=$ monensin, and $\mathrm{CIN}=$ cinnamaldehyde .

with the CON diet. Isobutyrate concentration was greater $(P<0.05)$ with the MON and CIN diets than the QTAN and CON diets. Total VFA concentration was not affected $(P>0.05)$ by treatment diets. Ammonia-N concentration decreased $(P<0.01)$ with the inclusion of feed additives and was least with the QTAN diet. Fermenter pH was similar between treatment diets $(P>0.05)$ averaging 6.43 .

The effect of treatments on BH and effluent FA are presented in Tables 6 and 7. Compared with the CON diet, the addition of condensed tannin and cinnamaldehyde had no effects $(P>0.05)$ on the BH of C18 unsaturated FA while the addition of monensin reduced $(P>0.05)$ the $\mathrm{BH}$ of $\mathrm{C} 18$ unsaturated FA. Addition of monensin decreased $(P<0.05)$ the concentrations of $\mathrm{C} 14$ iso and C15:0 compared to other diets. However, the concentrations of $\mathrm{C} 14: 0$ and $\mathrm{C} 15$ anteiso tended to increase $(P<0.06)$ with the CIN diet compared with the CON diet. Feed additives had no effects $(P>0.05)$ on the concentrations of C16 iso, C16:0 and C17:0 anteiso compared with the CON diet. The concentration of C18:0 decreased $(P<0.01)$ with the three feed additives and was least with the MON diet. Compared with the CON diet, the concentrations of trans C18:1 and VA increased $(P<0.05)$ with the MON and CIN diets and was greatest $(P<0.05)$ with the MON diet. The concentrations of $t 15$, $t 16$ and $C 18: 1 c 9$ increased $(P<0.05)$ with the CIN diet. Feed Additives had no effects $(P>0.05)$ on the concentrations of $t 4 / 5$, $t 6 / 8, t 9, t 10$ and $t 12 \mathrm{C} 18: 1$ isomers. The concentrations of $\mathrm{C} 18: 2 n 6$ and $\mathrm{C} 18: 3 n 3$ increased $(P<0.05)$ with the MON and $\mathrm{CIN}$ diets and were greatest with the MON diet. Concentration of $c 9 t 11$ CLA increased $(P<0.05)$ only with the QTAN diet while total FA concentration decreased $(P<0.05)$ with the QTAN and MON diets.

The effects of treatment diets on the DNA abundance of selected strains of ruminal bacteria are presented in Table 8 . Feed additives had no effects $(P>0.05)$ on the DNA abundance of Butyrivibrio SA and A. lipolytica. The DNA abundance of

Table 6

The effect of treatment diet on biohydrogenation of C18 unsaturated fatty acids.

\begin{tabular}{|c|c|c|c|c|c|c|}
\hline \multirow[t]{2}{*}{ Fatty acid } & \multicolumn{4}{|c|}{ Treatment } & \multirow[t]{2}{*}{ MSE } & \multirow[t]{2}{*}{$P$} \\
\hline & $\mathrm{CON}$ & QTAN & MON & CIN & & \\
\hline C18:1n9 & $0.72^{\mathrm{a}}$ & $0.72^{\mathrm{a}}$ & $0.65^{b}$ & $0.72^{\mathrm{a}}$ & 0.01 & 0.01 \\
\hline $\mathrm{C} 18: 2 n 6$ & $0.91^{\mathrm{a}}$ & $0.89^{a}$ & $0.82^{\mathrm{b}}$ & $0.89^{a}$ & 0.01 & 0.01 \\
\hline $\mathrm{C} 18: 3 n 3$ & $0.87^{\mathrm{a}}$ & $0.87^{a}$ & $0.81^{\mathrm{b}}$ & $0.88^{a}$ & 0.01 & 0.02 \\
\hline
\end{tabular}

\footnotetext{
a Means within raw with different superscripts differ $(P \leq 0.05)$.
}

b Means within raw with different superscripts differ $(P \leq 0.05)$.

$\mathrm{CON}=$ control, $\mathrm{QTAN}=$ quebracho condensed tannin, $\mathrm{MON}=$ monensin, and $\mathrm{CIN}=$ cinnamaldehyde. 
Table 7

The effect of treatment diets on effluent fatty acids (mg/g DM).

\begin{tabular}{|c|c|c|c|c|c|c|}
\hline \multirow[t]{2}{*}{ Fatty acid } & \multicolumn{4}{|c|}{ Treatment } & \multirow[t]{2}{*}{ MSE } & \multirow[t]{2}{*}{$P$} \\
\hline & $\mathrm{CON}$ & QTAN & MON & CIN & & \\
\hline $\mathrm{C} 14$ iso & $0.22^{\mathrm{b}}$ & $0.34^{\mathrm{a}}$ & $0.05^{c}$ & $0.15^{\mathrm{b}}$ & 0.049 & 0.01 \\
\hline C14:0 & 0.62 & 0.63 & 0.56 & 1.04 & 0.155 & 0.06 \\
\hline C15 anteiso & 0.63 & 0.86 & 0.64 & 1.16 & 0.173 & 0.06 \\
\hline C15:0 & $0.90^{\mathrm{b}}$ & $0.54^{\mathrm{b}}$ & $0.31^{c}$ & $1.61^{\mathrm{a}}$ & 0.161 & 0.01 \\
\hline C16 iso & 0.10 & 0.12 & 0.07 & 0.09 & 0.029 & 0.40 \\
\hline C16:0 & 12.7 & 12.4 & 11.5 & 17.2 & 3.171 & 0.36 \\
\hline C17:0 anteiso & 0.23 & 0.26 & 0.24 & 0.21 & 0.041 & 0.71 \\
\hline C18:0 & $61.9^{a}$ & $36.4^{\mathrm{b}}$ & $10.4^{c}$ & $40.0^{\mathrm{b}}$ & 1.570 & 0.01 \\
\hline$t 4 / 5$ & 0.13 & 0.08 & 0.08 & 0.09 & 0.029 & 0.37 \\
\hline$t 6 / 8$ & 0.13 & 0.06 & 0.07 & 0.11 & 0.060 & 0.15 \\
\hline$t 9$ & 0.78 & 0.62 & 0.65 & 0.88 & 0.163 & 0.11 \\
\hline$t 10$ & 3.60 & 2.99 & 3.55 & 3.03 & 0.525 & 0.22 \\
\hline$t 11$ (VA) & $7.64^{\mathrm{c}}$ & $6.53^{c}$ & $12.2^{\mathrm{a}}$ & $9.30^{\mathrm{b}}$ & 0.467 & 0.01 \\
\hline$t 12$ & 0.99 & 0.56 & 0.93 & 0.95 & 0.225 & 0.21 \\
\hline$t 15$ & $0.71^{\mathrm{b}}$ & $0.66^{\mathrm{b}}$ & $1.46^{\mathrm{a}}$ & $1.74^{\mathrm{a}}$ & 0.200 & 0.01 \\
\hline$t 16$ & $0.81^{a b}$ & $0.65^{b}$ & $0.26^{\mathrm{b}}$ & $1.28^{\mathrm{a}}$ & 0.262 & 0.01 \\
\hline trans $\mathrm{C} 18: 1$ & $14.8^{\mathrm{b}}$ & $12.9^{\mathrm{b}}$ & $19.4^{\mathrm{a}}$ & $18.1^{\mathrm{a}}$ & 1.026 & 0.01 \\
\hline C18:1 c9 & $8.43^{\mathrm{b}}$ & $8.13^{b}$ & $9.20^{\mathrm{b}}$ & $13.1^{\mathrm{a}}$ & 0.997 & 0.01 \\
\hline $\mathrm{C} 18: 2 n 6$ & $6.61^{\mathrm{c}}$ & $7.83^{b c}$ & $13.47^{a}$ & $8.59^{b}$ & 0.839 & 0.01 \\
\hline $\mathrm{C} 18: 3 n 3$ & $0.58^{c}$ & $0.82^{\mathrm{b}}$ & $1.15^{\mathrm{a}}$ & $0.77^{b}$ & 0.077 & 0.01 \\
\hline c9t11CLA & $0.57^{\mathrm{b}}$ & $1.98^{\mathrm{a}}$ & $0.33^{\mathrm{b}}$ & $0.62^{\mathrm{b}}$ & 0.414 & 0.01 \\
\hline$t 10 c 12$ CLA & 0.48 & 0.19 & 0.24 & 0.30 & 0.095 & 0.08 \\
\hline TFA & $133.9^{a}$ & $97.9^{\mathrm{b}}$ & $85.8^{\mathrm{b}}$ & $135.5^{\mathrm{a}}$ & 8.33 & 0.01 \\
\hline
\end{tabular}

a Means within raw with different superscripts differ $(P \leq 0.05)$.

b Means within raw with different superscripts differ $(P \leq 0.05)$.

c Means within raw with different superscripts differ $(P \leq 0.05)$.

TFA = Total fatty acids, $\mathrm{CON}=$ control, QTAN = quebracho condensed tannin, $\mathrm{MON}=$ monensin, and $\mathrm{CIN}=$ cinnamaldehyde .

Butyrivibrio VA increased $(P<0.05)$ with all feed additives while the DNA abundance of $B$. proteoclasticum decreased $(P<0.01)$ only with the MON and CIN diets.

\section{Discussion}

Consistent with the findings of others (Sliwinski et al., 2002; Busquet et al., 2006; Animut et al., 2008; Benchaar et al., 2008; Lourenço et al., 2008; Yang et al., 2010), the apparent digestibility of DM, OM and NDF and total VFA production were not affected by the inclusion of feed additives. However, others studies have reported reductions in DM and NDF digestibility with monensin (Poos et al., 1979; Anassori et al., 2012) and tannin (Bhatta et al., 2009; Grainger et al., 2009). This discrepancy among the different studies may be related to several factors such as diet composition, the period of adaptation to the product, the time when the samples were collected, and the type and concentrations of the feed additives (McGuffey et al., 2001; Bodas et al., 2012). Although these feed additives had no detrimental effect on the apparent digestibility of DM, OM and NDF and the total VFA production, they had variable impacts on apparent protein degradability, VFA profiles, and ammonia-N concentration in the present study suggesting that these additives have a 'milder' effects on the ruminal microbial activity and fermentation.

Previous reports suggested that cinnamaldehyde and tannin have the ability to modify the growth of rumen proteolytic bacteria either directly or indirectly by preventing access to the protein. The reductions in protein degradation seen iwith the CIN and QTAN diets in this study therefore may suggest that proteolytic and peptidolytic activities were reduced. In

Table 8

The effect of treatment diets on the DNA abundance (pg) of selected rumen bacteria at a given starting concentration.

\begin{tabular}{|c|c|c|c|c|c|c|}
\hline \multirow[t]{2}{*}{ Bacteria } & \multicolumn{4}{|c|}{ Treatment } & \multirow[t]{2}{*}{ MSE } & \multirow[t]{2}{*}{$P$} \\
\hline & $\mathrm{CON}$ & QTAN & MON & CIN & & \\
\hline Butyrivibrio SA, 18 ng $^{\mathrm{x}}$ & 31.63 & 28.28 & 29.71 & 28.13 & 2.856 & 0.61 \\
\hline Butyrivibrio VA, $18 \mathrm{ng}^{\mathrm{x}}$ & $0.02^{\mathrm{c}}$ & $0.04^{\mathrm{a}}$ & $0.05^{\mathrm{a}}$ & $0.03^{\mathrm{b}}$ & 0.006 & 0.05 \\
\hline B. proteoclasticum, $10 \mathrm{ng}^{\mathrm{x}}$ & $0.019^{\mathrm{b}}$ & $0.024^{a}$ & $0.002^{c}$ & $0.002^{\mathrm{c}}$ & 0.002 & 0.01 \\
\hline A. lipolytica, $60 \mathrm{ng}^{\mathrm{x}}$ & $0.15^{-3}$ & $0.20^{-3}$ & $0.17^{-3}$ & $0.17^{-3}$ & 0.00004 & 0.37 \\
\hline
\end{tabular}

a Means within raw with different superscripts differ $(P \leq 0.05)$.

b Means within raw with different superscripts differ $(P \leq 0.05)$.

c Means within raw with different superscripts differ $(P \leq 0.05)$.

$x$ Starting DNA concentration.

$\mathrm{CON}=$ control, $\mathrm{QTAN}=$ quebracho condensed tannin, $\mathrm{MON}=$ monensin, and $\mathrm{CIN}=$ cinnamaldehyde . 
previous continuous culture studies, Busquet et al. (2005b) and Tager and Krause (2010) reported that protein digestibility and bacterial nitrogen flow was depressed with cinnamon oil. Cardozo et al. (2004) also reported that $7.5 \mathrm{mg} / \mathrm{kg}$ DM cinnamaldehyde addition reduced peptidolysis in a continuous culture study. The suppressing of protein fermentation might be also due to formation of complexes between tannin and protein (Makkar et al., 1995) or the inhibition of the activities of the protease enzyme by tannin. Previous continuous culture (Khiaosa-Ard et al., 2009; Hassanat and Benchaar, 2012) and in vivo (McSweeney et al., 2001) experiments have also reported similar reductions in protein digestibility with tannin. The high affinity of tannins to proteins may explain the pronounced effect of tannins on protein apparent degradation in this study. It is well documented that tannins have higher affinity to proteins than to polysaccharides (Patra and Saxena, 2009). A decrease in the rumen protein degradability in the rumen is beneficial for ruminants as they increase the supply of dietary nitrogen to the lower intestine for production.

The decreases in ammonia-N concentration with the CIN and QTAN diets could be partly due to decrease in deamination of amino acids or low availability of amino acids resulted from decrease in protein degradation. Although the degradability of protein was not affected by the addition of monensin, the reduced ammonia-N concentration seen with the MON diet suggests that the deamination process was inhibited. Previous in vitro studies with monensin addition had also showed that the decrease in ammonia- $\mathrm{N}$ concentration was associated with an accumulation of amino acids or peptide indicating that monensin inhibits deamination to a greater extent than proteolysis (Whetstone et al., 1981; Russell and Martin, 1984).

The concentration of propionate increased with the MON and QTAN diets, while the concentration of acetate decreased with the MON and CIN diets. The pattern of VFA observed in the present study with these additives was marked by a strong decrease in acetate to propionate ratio, suggesting that these additives inhibited acetate producing bacteria particularly with the MON diet. Numerous in vitro and in vivo studies demonstrated that the addition of these additives increased the proportion of propionate and reduced the proportion of acetate and butyrate. Fellner et al. (1997) reported that the addition of monensin $(2.9 \mu \mathrm{M}$ of fermenter contents) decreased the molar percentage of acetate and increased the molar percentage of propionate, decreasing the ratio of acetate to propionate from 3.0 to 1.7. Ipharraguerre and Clark (2003) reviewed the effects of feeding monensin to lactating dairy cows and reported that monensin usually increased the molar proportion of propionate and decreased acetate to propionate ratio. In an in vitro experiment, 31.2 and $312 \mathrm{mg} / \mathrm{L}$ doses of cinnamaldehyde decreased the molar proportion of acetate and increased the molar proportion of propionate (Busquet et al., 2005a). Busquet et al. (2006) used varying doses of cinnamaldehyde from 3 to $3000 \mathrm{mg} / \mathrm{L}$, and observed no effect on the molar proportion of acetate and butyrate, but an increase of the molar proportion of propionate with the highest dose. Bhatta et al. (2009) reported an increase in in vitro propionate production when supplementing condensed tannin from either quebracho $(13.3 \mathrm{~g} / \mathrm{kg}$ and $36.7 \mathrm{~g} / \mathrm{kg}$ tannin of DM) or mimosa $(15.0 \mathrm{~g} / \mathrm{kg}$ tannin of DM). The acetate to propionate ratio decreased when feeding Acacia mearnsii extract as sources of tannin at a rate of $78.9 \mathrm{~g} / \mathrm{kg} \mathrm{DM}$ in a rumen simulation technique system (Khiaosa-Ard et al., 2009). The changes in VFA portions may be nutritionally advantageous, because propionate is one of the main sources of metabolizable energy for ruminants and it is energetically more effective. In the rumen, gram-positive bacteria are generally acetate and butyrate producing bacteria, while gram-negative bacteria are generally propionate-producing bacteria (Stewart, 1991). Therefore, the results of this study suggest that the feed additives ae more inhibitory to the gram-positive bacteria than gram-negative bacteria. Monensin is known to depress or inhibit rumen microorganism growth, especially gram positive bacteria, and stimulate the development of bacteria that produce propionic acid (McGuffey et al., 2001; Ipharraguerre and Clark, 2003). In an in vitro study, Chen and Wolin (1979) reported that bacteria that produce lactic, acetic, butyric and formic acids and hydrogen as main end products are susceptible to ionophores whereas succinic-and propionic acid-producing bacteria are resistant. Previous in vitro studies (Nemoto et al., 1995; Nelson et al., 1997) reported that growth and cellulolytic activity of Fibrobacter succinogenes were more inhibited by condensed tannin levels than the growth and activity of Prevotella ruminicola and Streptococcus bovis (Nelson et al., 1997). Similarly, McSweeney et al. (2001) observed a decrease of $F$. succinogenes and Ruminococcus spp. in ewes supplemented with $60 \mathrm{~g}$ of condensed tannin $/ \mathrm{kg}$ of DM.

The lower concentration of $\mathrm{C} 18: 0$ along with the greater concentrations of $\mathrm{C} 18: 2 n 6$ and $\mathrm{C} 18: 3 n 3$ in fermenters fed the MON diet suggest reductions in the apparent $\mathrm{BH}$ of $\mathrm{C} 18: 2 n 6$ and $\mathrm{C} 18: 3 n 3$ in fermenters fed the MON diet consistent with the findings (Fellner et al., 1997; Benchaar et al., 2006; Odongo et al., 2007). The observed reduction in their BH may indicate less lipid hydrolysis and/or isomerization of the free $\mathrm{C} 18: 2 \mathrm{n} 6$ and $\mathrm{C} 18: 3 \mathrm{n} 3$ in the monensin-fed fermenters. However, because the significant reduction in the C18:0 formation with the monensin diet in this study and the monensin known effects on the growth of gram-positive bacteria that produce hydrogen (Chen and Wolin, 1979), it is most likely that monensin effect on $\mathrm{BH}$ resulted from reductions in the first isomerization step of $\mathrm{C} 18: 2 n 6$ and $\mathrm{C} 18: 3 n 3$. Additionally, the lack of monensin effect on the DNA abundance of A. lipolytica further supports that monensin had no effects on lipids hydrolysis. The lack of effect of condensed tannin and cinnamaldehyde on the BH of C18 unsaturated FA is consistent with the findings of others (Benchaar and Chouinard, 2009; Khiaosa-Ard et al., 2009) but in contrast to others (Cabiddu et al., 2009; Vasta et al., 2009b). This inconsistency is most likely related to differences in supplement source, dose level and diets composition. The reduction in the formation of $\mathrm{C} 18: 0$ along with the accumulation of trans $\mathrm{C} 18: 1$, VA in particular, is consisting with the findings of others (Fellner et al., 1997; Benchaar et al., 2006; AlZahal et al., 2008) and may suggest that monensin interrupted the complete BH of C18 trans FA leading to a decrease in the concentration of C18:0 and increase in trans C18:1, VA in particular. In a continuous culture study, Fellner et al. (1997) reported that the concentration of VA was greater with monensin $(2.5 \mu \mathrm{M}$ final concentration) compared with control. Other in vivo studies (Benchaar et al., 2006; AlZahal et al., 2008) also reported greater VA concentration with monensin diets ( $350 \mathrm{mg} /$ day and $22 \mathrm{~g} / \mathrm{kg}$ of DM respectively). Since the vast majority of $c 9 t 11$ 
CLA is produced in animal tissues via $\Delta^{9}$ desaturase using VA as its substrate (Griinari et al., 2000), increasing the formation and flow of VA from the rumen is therefore desirable as it would aid in the process of developing healther ruminantderived food products. Although the mode of action could not be determined, monensin may have reduced group B bacteria and/or inhibits their reductase activity. Kemp and Lander (1984) classified bacteria involved in BH into two groups based on the reaction and end products of BH. Accordingly, group A bacteria, R. albus and Butyrivibrio sp., are able to hydrogenate C18:2n6 and C18:3n3, with VA being their major end product. Group B bacteria, Fusocillus babrahamensis, Fusocillus sp. and an unnamed gram-negative rod (R8/5), are able to utilize VA as one of the main substrates to form C18:0 as the end product. Wallace et al. (2006) reported that B. proteoclasticus has the ability to produce C18:0 from C18:2n6 and B. proteoclasticum is phylogenetically related to Fusocillus spp. Boeckaert et al. (2008) identified both B. proteoclasticum as well as B. hungatei groups as group $B$ bacteria. In this study, the reduction in the concentration of C18:0 with the monensin diet was associated with reductions in the DNA abundance of $B$. proteoclasticum suggesting that monensin effect on VA formation may in part be explained by its effects on B. proteoclasticum. To the best of our knowledge, this study is the first to report monensin effects on B. proteoclasticum. Addition of cinnamaldehyde in this study also reduced the formation of C18:0 and increased the formation of VA but to a lower extent than that of monensin supplement. Such increase in the accumulation of trans C18:1, VA in particular, also suggests that cinnamaldehyde reduced the terminal step of BH, the reduction of VA to C18:0, possibly by affecting the group B bacteria. As with the MON diet, the reduction in the concentration of C18:0 with the CIN diet in this study was also associated with reductions in the DNA abundance of B. proteoclasticum which further supports the important role of these bacteria in trans C18:1 reductions to C18:0.

The greater concentration of $c 9 t 11$ CLA in effluent of the QTAN diet compared with the CON diet is consistent with the findings of others (Khiaosa-Ard et al., 2009; Vasta et al., 2009a). The inclusion of condensed tannin in the diet did not affect the accumulation of C18:2n 6 but increased the accumulation of $c 9 t 11$ CLA suggesting that condensed tannin had no effect on oil hydrolysis. The increased c9t11 CLA with the QTAN diet may have resulted from a delay in the c9t11 CLA reduction step. The decrease in C18:0 concentration with the QTAN diet is consistent with the findings of Khiaosa-Ard et al. (2009) and Vasta et al. (2009a) whom also reported reductions in the concentrations of C18:0 when incubating ruminal fluid with tannins. Although C18:0 concentration decreased with the QTAN diet, the concentration of trans C18:1 and VA did not increase suggesting that other unknown BH intermediates may have been produced. For example, Jenkins et al. (2006) showed of the total C18:1c9 that disappeared from rumen cultures, approximately 70\% was transferred into trans $\mathrm{C} 18: 1$ and $\mathrm{C} 18: 0$ and $30 \%$ was transformed into hydroxystearic acid and ketostearic acid. Additionally, the lack of QTAN diet effect on the DNA abundance of B. proteoclasticus further supports that condensed tannin had no effects on the group B bacteria. However, Vasta et al. (2009b) reported that inclusion of tannin to a barley-based concentrate and lucerne hay diet for sheep increased the population of $B$. fibrisolvens, while the growth of B. proteoclasticus reduced.

Using 16S rDNA sequence data, Paillard et al. (2007a) constructed a phylogenetic tree that contains two main groups of rumen Butyrivibrio bacteria called vaccenic acid-producing (Butyrivibrio VA) and stearic acid-producing (Butyrivibrio SA). Although both groups formed VA from C18:2n6, only Butyrivibrio SA bacteria produced C18:0 (Paillard et al., 2007b). Dietary supplements in this study had no effect on the DNA abundance for Butyrivibrio SA and to the best of our knowledge, this study is the first to report these feed additives effects on Butyrivibrio SA. Fuentes et al. (2009) and Gudla et al. (2012) also reported no correlations between Butyrivibrio SA and C18:0 flow under low rumen pH conditions. Kim et al. (2008) and Huws et al. (2010) also reported that DNA abundance from the Butyrivibrio SA-producing group did not correlate with the C18:0 concentrations suggesting that Butyrivibrio SA-producing group may not indeed by the main C18:0 producer in the rumen. These results, therefore, would suggest that other, yet-uncultivated microbial species might be involved in C18:0 production and might fulfill a more important role in the final step of the BH process. Additionally, it is still also possible that supplements decreased the capacity of these bacteria to hydrogenate trans $\mathrm{C} 18: 1$ rather than the bacteria as such. A recent study by Maia et al. (2010) reported that the inhibitory-growth effects of unsaturated FA on bacteria may be mediated via metabolic means rather than disruption of cell membrane. Additionally, Huws et al. (2011) suggested that Butyrivibrio SA may not play the dominant role in C18:0 formation and other yet-uncultivated bacteria, particularly those belonging to the genera Prevotella and Anaerovoax, and unclassified Clostridiales and Ruminococcaceae may play a role in biohydrogenation.

\section{Conclusions}

Results from the present study shows that none of the feed additives had an effect on apparent digestibility of DM and NDF, however, apparent digestibility of protein was lower in diets supplemented with condensed tannin and cinnamaldehyde. Acetate concentration decreased with the addition of monensin and cinnamaldehyde while the concentration of propionate increased with the addition of monensin and condensed tannin. The concentration of C18:0 decreased with the three feed additives, particularly with monensin. The concentration of VA increased only with the MON and CIN diets and this increase corresponded with a decrease in the DNA abundance of $B$. proteoclasticum. None of the feed additives had any effects on the DNA abundance of Butyrivibrio SA and A. lipolytica. Monensin and cinnamaldehyde effects on VA formation may be therefore explained in part by their effects on B. proteoclasticum. Cinnamaldehyde could be a safe alternative to antibiotic (monensin) to alter bacterial populations involved in ruminal BH. However, further research is still needed to confirm these feed additives effects under in vivo conditions. 


\section{Conflict of interest}

\section{Authors don't have conflict of interest with this manuscript.}

\section{References}

AbuGhazaleh, A.A., Buckles, W.R., 2007. The effect of solid dilution rate and lipid source on trans-C18:1 and conjugated linoleic acid production by ruminal microbes in continuous culture. J. Dairy Sci. 90, 963-969.

AbuGhazaleh, A.A., Jacobson, B.N., 2007. Production of trans-C18:1 and conjugated linoleic acid production by ruminal microbes in continuous culture fermenters fed diets containing fish oil and sunflower oil with decreasing levels of forage. Animal 1, 660-665.

AbuGhazaleh, A.A., Potu, R.B., Ibrahim, S., 2009. Short communication: the effect of substituting fish oil in dairy cow diets with docosahexaenoic acid-micro algae on milk composition and fatty acids profile. J. Dairy Sci. 92, 6156-6159.

AlZahal, O., Odongo, N., Mutsvangwa, T., Or-Rashid, M., Duffield, T., Bagg, R., McBride, B., 2008. Effects of monensin and dietary soybean oil on milk fat percentage and milk fatty acid profile in lactating dairy cows. J. Dairy Sci. 91, 1166-1174.

Anassori, E., Dalir-Naghadeh, B., Pirmohammadi, R., Taghizadeh, A., Asri-Rezaei, S., Farahmand-Azar, S., Besharati, M., Tahmoozi, M., 2012. In vitro assessment of the digestibility of forage based sheep diet, supplemented with raw garlic, garlic oil and monensin. Vet. Res. Forum. 3, 5-11.

Animut, G., Goetsch, A.L., Puchala, R., Patra, A.K., Sahlu, T., Varel, V.H., Wells, J., 2008. Methane emission by goats consuming different sources of condensed tannins. Anim. Feed Sci. Technol. 144, 228-241.

AOAC, 1990. Association of Official Analytical Chemists. Official Methods of Analysis, 15th ed, Washington, DC, USA.

AOAC, 2000. Association of Official Analytical Chemists. Official Methods of Analysis.

Benchaar, C., Petit, H.V., Berthiaume, R., Whyte, T.D., Chouinard, P.Y., 2006. Effects of addition of essential oils and monensin premix on digestion, ruminal fermentation, milk production, and milk composition in dairy cows. J. Dairy Sci. 89, 4352-4364.

Benchaar, C., McAllister, T.A., Chouinard, P., 2008. Digestion, ruminal fermentation, ciliate protozoal populations, and milk production from dairy cows fed cinnamaldehyde, quebracho condensed tannin, or Yucca schidigera saponin extracts. J. Dairy Sci. 91, 4765-4777.

Benchaar, C., Chouinard, P.Y., 2009. Assessment of the potential of cinnamaldehyde, condensed tannins, and saponins to modify milk fatty acid composition of dairy cows. J. Dairy Sci. 92, 3392-3396.

Bhatta, R., Uyeno, Y., Tajima, K., Takenaka, A., Yabumoto, Y., Nonaka, I., Kurihara, M., 2009. Difference in the nature of tannins on in vitro ruminal methane and volatile fatty acid production and on methanogenic archaea and protozoal populations. J. Dairy Sci. 92, 5512-5522.

Bodas, R., Prieto, N., García-González, R., Andrés, S., Giráldez, F.J., López, S., 2012. Manipulation of rumen fermentation and methane production with plant secondary metabolites. Anim. Feed Sci. Technol. 176, 78-93.

Boeckaert, C., Vlaeminck, B., Fievez, V., Maignien, L., Dijkstra, J., Boon, N., 2008. Accumulation of trans C18:1 fatty acids in the rumen after dietary algal supplementation is associated with changes in the Butyrivibrio community. Appl. Environ. Microbiol. 74, 6923-6930.

Busquet, M., Calsamiglia, S., Ferret, A., Cardozo, P.W., Kamel, C., 2005a. Effects of cinnamaldehyde and garlic oil on rumen microbial fermentation in a dual flow continuous culture. J. Dairy Sci. 88, 2508-2516.

Busquet, M., Calsamiglia, S., Ferret, A., Kamel, C., 2005b. Screening for effects of plant extracts and active compounds of plants on dairy cattle rumen microbial fermentation in a continuous culture system. Anim. Feed Sci. Technol. 123-124, 597-613.

Busquet, M., Calsamiglia, S., Ferret, A., Kamel, C., 2006. Plant extracts affect in vitro rumen microbial fermentation. J. Dairy Sci. 89, $761-771$.

Cabiddu, A., Molle, G., Decandia, M., Spada, S., Fiori, M., Piredda, G., Addis, M., 2009. Responses to condensed tannins of flowering sulla (Hedysarum coronarium L.) grazed by dairy sheep. Part 2: Effects on milk fatty acid profile. Livest. Sci. 123, $230-240$.

Cardozo, P.W., Calsamiglia, S., Ferret, A., Kamel, C., 2004. Effects of natural plant extracts on ruminal protein degradation and fermentation profiles in continuous culture. J. Anim. Sci. 82, 3230-3236.

Chaves, A.V., Stanford, K., Dugan, M.E.R., Gibson, L.L., McAllister, T.A., VanHerk, F., Benchaar, C., 2008. Effects of cinnamaldehyde, garlic and juniper berry essential oils on rumen fermentation, blood metabolites, growth performance, and carcass characteristics of growing lambs. Livest. Sci. 117, 215-224.

Chen, M., Wolin, M.J., 1979. Effect of monensin and lasalocid-sodium on the growth of methanogenic and rumen saccharolytic bacteria. Appl. Environ. Microbiol. 38, 72-77.

Crumb, D.J., 2011. Conjugated linoleic acid (CLA): an overview. Int. J. Appl. Res. Nat. Prod. 4, 12-18.

Fellner, V., Sauer, F.D., Kramer, J., 1997. Effect of nigericin, monensin, and tetronasin on biohydrogenation in continuous flow-through ruminal fermenters. J. Dairy Sci. 80, 921-928.

Fuentes, M.C., Calsamiglia, S., Cardozo, P.W., Vlaeminc, B., 2009. Effect of pH and level of concentrate in the diet on the production of biohydrogenation intermediates in a dual-flow continuous culture. J. Dairy Sci. 92, 4456-4466.

Grainger, C., Clarke, T., Auldist, M.J., Beauchemin, K.A., McGinn, S.M., Waghorn, G.C., Eckard, R.J., 2009. Potential use of Acacia mearnsii condensed tannins to reduce methane emissions and nitrogen excretion from grazing dairy cows. Can. J. Anim. Sci. 89, $241-251$.

Griinari, J.M., Corl, B.A., Lacy, S.H., Chouinard, P.Y., Nurmela, K.V., Bauman, D.E., 2000. Conjugated linoleic acid is synthesized endogenously in lactating dairy cows by delta-9-desaturase. J. Nutr. 130, 2285-2291.

Gudla, P., Ishlak, A., AbuGhazaleh, A.A., 2012. The Effect of forage level and oil supplement on Butyrivibrio fibrisolvens and Anaerovibrio lipolytica in continuous culture fermenters, Asian Australas. J. Anim. Sci. 25, 234-239.

Hassanat, F., Benchaar, C., 2012. Assessment of the effect of condensed (acacia and quebracho) and hydrolysable (chestnut and valonea) tannins on rumen fermentation and methane production in vitro. J. Sci. Food Agric. 93, 332-339.

Huws, S., Lee, M., Muetzel, S., Scott, M., Wallace, R., Scollan, N., 2010. Forage type and fish oil cause shifts in rumen bacterial diversity. FEMS Microbiol. Ecol. 73, 396-407

Huws, S., Kim, E., Lee, M., Scott, M., Tweed, J., Pinloche, E., Scollan, N., 2011. As yet uncultured bacteria phylogenetically classified as Prevotella, Lachnospiraceae incertae sedis and unclassified Bacteroidales, Clostridiales and Ruminococcaceae may play a predominant role in ruminal biohydrogenation. Environ. Microbiol. 13, 1500-1512.

Ipharraguerre, I.R., Clark, J.H., 2003. Usefulness of ionophores for lactating dairy cows: a review. Anim. Feed Sci. Technol. $106,39-57$.

Jenkins, T.C., 1987. Effect of fats and fatty acid combinations on ruminal fermentation in semi-continuous in vitro cultures. J. Anim. Sci. 64, 1526-1532.

Jenkins, T.C., AbuGhazaleh, A.A., Freeman, S., Thies, E.J., 2006. The production of 10-hydroxystearic and 10-ketostearic acids is an alternative route of oleic acid transformation by the ruminal microbiota in cattle. J. Nutr. 136, 926-931.

Kemp, P., Lander, D.J., 1984. Hydrogenation in vitro of $\alpha$-linolenic acid to stearic acid by mixed culture of pure strains of rumen bacteria. J. Gen. Microbiol. 130, 527-533.

Khiaosa-Ard, R., Bryner, S.F., Scheeder, M.L., Wettstein, H.-R., Leiber, F., Kreuzer, M., Soliva, C.R., 2009. Evidence for the inhibition of the terminal step of ruminal alpha-linolenic acid biohydrogenation by condensed tannins. J. Dairy Sci. 92, 177-188.

Kim, E.J., Huws, S.A., Lee, M.R.F., Wood, J.D., Muetzel, S.M., Wallace, R.J., Scollan, N.D., 2008. Fish oil increases the duodenal flow of long chain polyunsaturated fatty acids and trans-11 18:1 and decreases 18:0 in steers via changes in the rumen bacterial community. J. Nutr. 138 , 889-896.

Kramer, J.K.G., Fellner, V., Dugan, M.E.R., Sauer, F.D., Mosoba, M.M., Yurawecz, M.P., 1997. Evaluating acid and base catalysts in the methylation of milk and rumen fatty acids with special emphasis on conjugated dienes and total trans fatty acids. Lipids 32,1219-1228.

Lourenço, M., Cardozo, P., Calsamiglia, S., Fievez, V., 2008. Effects of saponins, quercetin, eugenol, and cinnamaldehyde on fatty acid biohydrogenation of forage polyunsaturated fatty acids in dual-flow continuous culture fermenters. J. Anim. Sci. 86, 3045-3053. 
Maia, M.R., Chaudhary, L.C., Bestwick, C.S., Richardson, A.J., McKain, N., Larson, T.R., Graham, I.A., Wallace, R.J., 2010. Toxicity of unsaturated fatty acids to the biohydrogenating ruminal bacterium, Butyrivibrio fibrisolvens. BMC Microbiol. 10, 52.

Makkar, H.P.S., Beeker, K., Abel, H.J., Szegletti, G., 1995. Degradation of condensed tannins by rumen microbes exposed to quebracho tannins (QT) in rumen simulation technique (RUSITEC) and effects of QT on fermentative processes in the RUSITEC. J. Sci. Food Agric. 69, 495-500.

McGuffey, R.K., Richardson, L.F., Wilkinson, J.I.D., 2001. Ionophores for dairy cattle: current status and future outlook. J. Dairy Sci. 84, $194-203$.

McSweeney, C.S., Palmer, B., McNeill, D.M., Krause, D.O., 2001. Microbial interactions with tannins: nutritional consequences for ruminants. Anim. Feed Sci. Technol. 91, 83-93.

Nelson, K.E., Pell, A.N., Doane, P.H., Giner-Chavez, B.I., Schofield, P., 1997. Chemical and biological assays to evaluate bacterial inhibition by tannins. J. Chem. Ecol. 23, 1175-1194.

Nemoto, K., Osawa, R., Hirota, K., Ono, T., Miyake, Y., 1995. An investigation of gram-negative tannin-protein complex degrading bacteria in fecal flora of various mammals. J. Vet. Med. Sci. 57, 921-926.

Odongo, N.E., Or-Rashid, M.M., Bagg, R., Vessie, G., Dick, P., Kebreab, E., France, J., McBride, B.W., 2007. Long-term effects of feeding monensin on milk fatty acid composition in lactating dairy cows. J. Dairy Sci. 90, 5126-5133.

Patra, A.K., Saxena, J., 2009. Dietary phytochemicals as rumen modifiers: a review of the effects on microbial populations. Anton. van Leeuwenhoek. 96, 363-375.

Paillard, D., McKain, N., Chaudhary, L.C., Walker, N.D., Pizette, F., Koppova, I., Vercoe, P.E., 2007a. Relation between phylogenetic position, lipid metabolism and butyrate production by different Butyrivibrio-like bacteria from the rumen. Anton. van Leeuwenhoek. 91, 417-422.

Paillard, D., McKain, N., Rincon, M.T., Shingfield, K.J., Givens, D.I., Wallace, R.J., 2007b. Quantification of ruminal Clostridium proteoclasticum by real-time PCR using a molecular beacon approach. J. Appl. Microbiol. 103, 1251-1261.

Poos, M.I., Hanson, T.L., Klopfenstein, T.J., 1979. Monensin effects on diet digestibility, ruminal protein bypass and microbial protein synthesis. J. Anim. Sci. 48, 1516-1524.

Potu, R.B., AbuGhazaleh, A.A., Hastings, D., Jones, K., Ibrahim, S.A., 2011. The effect of lipid supplements on ruminal bacteria in continuous culture fermenters varies with the fatty acid composition. J. Microbiol. 49, 216-223.

Reilly, K., Attwood, G.T., 1998. Detection of Clostridium proteoclasticum and closely related strains in the rumen by competitive PCR. Appl. Environ. Microbiol. 64, 907-913.

Russell, J.B., Martin, S.A., 1984. Effects of various methane inhibitors on the fermentation of amino acids by mixed rumen microorganisms in vitro. J. Anim. Sci. 59, 1329-1338.

Sliwinski, B.J., Kreuzer, M., Wettstein, H.R., Machmuller, A., 2002. Rumen fermentation and nitrogen balance of lambs fed diets containing plant extracts rich in tannins and saponins, and associated emissions of nitrogen and methane. Arch. Anim. Nutr. 56, 379-392.

Stern, M.D., Hoover, W.H., 1990. The Dual Floe Continuous Culture System. Pages 17-32 in Continuous Culture Fermenters: Frustration or Fermentation? In: Workshop Handbook for NEADSA-ASAS Regional Meeting, Chazy, NY.

Stewart, C.S., 1991. The rumen bacteria. In: Jouany, J.P. (Ed.), Rumen Microbial Metabolism and Ruminant Digestion. , INRA ed, pp. 15-26, Paris, France.

Tager, L.R., Krause, K.M., 2010. Effects of cinnamaldehyde, eugenol, and capsicum on fermentation of a corn-based dairy ration in continuous culture. Can. J. Anim. Sci. 90, 413-419.

Van Soest, P.J., Robertson, J.B., Lewis, B.A., 1991. Methods for dietary fiber, neutral detergent fiber, and non-starch polysaccharides in relation to animal nutrition. J. Dairy Sci. 74, 3583-3597.

Vasta, V., Makkar, H., Mele, M., Priolo, A., 2009a. Ruminal biohydrogenation as affected by tannins in vitro. Br. J. Nutr. 102, 82-92.

Vasta, V., Mele, M., Serra, A., Scerra, M., Luciano, G., Lanza, M., Priolo, A., 2009b. Metabolic fate of fatty acids involved in ruminal biohydrogenation in sheep fed concentrate or herbage with or without tannins. J. Anim. Sci. 87, 2674-2684.

Wallace, R.J., Chaudhary, L.V., McKain, N., McEwan, N.R., Richardson, A.J., Vercoe, P.E., Walker, N.D., Paillard, D., 2006. Clostridium proteoclasticum: a ruminal bacterium that forms stearic acid from linoleic acid. FEMS Microbiol. Lett. 265, 195-201.

Whetstone, H.D., Davis, C.L., Bryant, M.P., 1981. Effect of monensin on breakdown of protein by ruminal microorganisms in vitro. J. Anim. Sci. 55, 803-809.

Yang, W.Z., Ametaj, B.N., Benchaar, C., Beauchemin, K.A., 2010. Dose response to cinnamaldehyde supplementation in growing beef heifers: ruminal and intestinal digestion. J. Anim. Sci. 88, 680-688 